\title{
A direct comparison of the performance of public-private partnerships with that of traditional contracting
}

\section{Bruno Rodrigues ${ }^{1}$}

Cesar Zucco²

${ }^{1}$ Banco Nacional de Desenvolvimento Econômico e Social (BNDES), Rio de Janeiro / RJ — Brazil

2 Fundação Getulio Vargas / Escola Brasileira de Administração Pública e de Empresas, Rio de Janeiro / RJ — Brazil

This paper assesses the city of Belo Horizonte's experience building school infrastructure through public-private partnerships (PPPs). Between 2009 and 2015, Belo Horizonte built very similar schools using both PPPs and traditional public contracting (TPC). As the choice of mode of contracting was unrelated to our outcomes of interest, the experience constitutes a quasi-experiment that allows for a simple and direct comparison of PPPs to TPC. We examine construction- and operation-phase outcomes measured using administrative data and a survey of school administrators. We find that schools constructed under the PPP contracting model outperformed those built using TPCs in most outcomes.

Keywords: impact evaluation; public-private partnerships; pubic contracting; quasi-experiment; social infrastructure.

\section{Uma comparação direta do desempenho de uma PPP com o modelo tradicional de contratação pública}

Este artigo avalia a experiência do município de Belo Horizonte na construção e operação de infraestrutura escolar por meio de Parcerias Público-Privadas (PPPs). Entre 2009 e 2015, Belo Horizonte construiu escolas similares usando tanto PPPs como o modelo tradicional de contratação pública (MTCP). Dado que a escolha do modelo de contratação não tinha relação causal direta com os resultados avaliados, pode-se afirmar que essa experiência constitui um quasi experimento que permite a comparação simples e direta das PPPs com o MTCP. Avaliamos os principais resultados nas fases de construção e operação usando dados administrativos fornecidos pela prefeitura e com questionário aplicado aos diretores das escolas. O artigo mostra que as escolas construídas no modelo de PPP tiveram um desempenho melhor do que as que usaram o MTCP.

Palavras-chave: avaliação de impacto; contratação pública; infraestrutura social; Parcerias Público-Privadas; quasi experimento.

\section{Una comparación directa del desempeño de una CPP con el modelo tradicional de contratación pública}

Este artículo evalúa la experiencia del municipio de Belo Horizonte en la construcción y operación de infraestructura escolar a través de una Colaboración Público-Privada (CPP). Entre 2009 y 2015, Belo Horizonte construyó escuelas similares usando tanto CPPs como el modelo tradicional de contratación pública (MTCP). Dado que la elección del modelo de contratación no tenía relación causal con los resultados evaluados, se puede afirmar que esa experiencia constituye un cuasi experimento que permite la comparación simple y directa de las CPPs con el MTCP. Evaluamos los principales resultados en las etapas de construcción y operación usando datos administrativos sumistrados por la alcaldía y con cuestionario aplicado a los directores de las escuelas. El artículo muestra que las escuelas construidas en el modelo de CPP tuvieron un desempeño mejor que las que usaron el MTCP.

Palabras clave: evaluación de impacto; contratación pública; infraestructura social; Colaboración Público-Privada; cuasi experimento.

DOI: http://dx.doi.org/10.1590/0034-761220170313

Article received on October 11, 2017 and accepted on April 5, 2018.

[Original version]

The authors would like to thank Armando Castelar and Flávio Menezes for comments on earlier versions of this paper, and Michele Bergamini, Cristiano Castro, Jane Menezes and Alessandra Cardoso for invaluable help in the field. 


\section{INTRODUCTION}

In 2009, the incoming government of Belo Horizonte - one of Brazil's largest cities ${ }^{1}$ - prioritized the expansion of preschool enrollment, which called for the construction of a large number of new schools. After initially struggling to improve the city's educational infrastructure using traditional public contracting (TPC), the administration introduced a novel program to build and operate schools using public-private partnerships (PPPs). In this paper, we examine whether this effort was successful.

PPPs have been used for decades at the federal, state and local levels across a range of policy areas as an alternative to TPC. Despite the attention given to the topic in the academic literature, most of which touts the advantages of PPPs relative to TPC, there are still surprisingly few studies that perform a head-to-head comparison of the construction and operational performance of the two models. The dearth of academic work is largely due to a lack of data on TPC projects and to difficulties in setting up a clear comparison between PPP and TPC projects in similar policy areas, carried out during similar periods and locales.

The Belo Horizonte example constitutes a quasi-experiment which allows for a direct comparison of the performance of PPPs relative to that of TPC in terms of school construction and operation. Between 2009 and 2015, the city built a number of preschool units using both procurement methods simultaneously. We argue that the choice of contracting method for each school was driven by factors unrelated to the outcomes we analyze and, as such, the two sets of schools are in fact very comparable.

Although we are not able to compare construction and operational costs, we analyze both administrative data and a survey of school principals from both groups and examine outcomes that include construction time and post-construction operational performance. We find that the PPP projects outperformed traditional contracting in almost all of the outcomes examined.

We begin with a review of the literature comparing the performance of PPPs with that of traditional contracting, focusing particularly on PPPs in education. We then describe the institutional context and Belo Horizonte's school building initiative. In the subsequent section, we present our research design and evidence that the two groups of schools are, in fact, comparable. Finally, we describe the data and present our results, offering concluding remarks and analysis.

\section{COMPARING PPPS WITH TRADITIONAL PUBLIC CONTRACTING}

Theoretical work analyzing whether governments should provide services in-house or by contracting out suggested that privatization could lead to lower costs, but to ambiguous outcomes in terms of quality, at least in some policy areas (Hart, Shleifer and Vishny, 1997). Subsequent work that accounted for the possibility of hybrid service provision arrangements (i.e. public-private collaboration) suggested that these often yield superior outcomes (Bennett and Iossa, 2006). Much empirical work has followed in attempting to assess the relative performance of PPP.

Any such assessment requires an operational definition of PPPs, but these range considerably. In the broadest possible sense, PPPs can be defined to include partnerships not only with businesses,

\footnotetext{
${ }^{1}$ Brazil has just over 5,000 municipalities. With a population of about 2.5 million, Belo Horizonte is the sixth largest city (and third largest metropolitan area) in the country. We use the terms "city" and "municipality" interchangeably in this article.
} 
but also community or voluntary organizations and NGOs. The purpose and function of PPPs also varies widely, and could include purposes beyond infra-structure construction and service delivery, such as policy design, planning, coordination and evaluation (Bovaird, 2004). In this paper, we focus on a comparison of PPPs to build and operate public assets (i.e. schools) vis-à-vis the what we label "traditional public contracting".

In what is typically described as the "traditional" model for infrastructure projects, governments hire a contractor for the project's construction phase while retaining responsibility for the maintenance and operation of the asset in the post-construction phase. Duffield aptly defines this type of traditional contracting as "capital projects that are financed by government through a short term design and construct contract. Ongoing operation of these facilities and responsibility for service delivery remains with government departments and/or agencies" (Duffield, 2008:8).

Even without a unique or standard definition of what constitutes a public-private partnership, PPPs depart from this model in several different ways. The case in Belo Horizonte conforms to the World Bank's definition of PPPs as a "long-term contract between a private party and a government entity, for providing a public asset or service, in which the private party bears significant risk and management responsibility, and remuneration is linked to performance" (World Bank, 2014). In the broader literature, however, payment linked to performance is not typically considered essential ( $\mathrm{Li}$ et al., 2005; Leiringer, 2006), and while most authors refer to some risk sharing, they do not stipulate that the risk incurred by the private party be significant (Jacobson and Choi, 2008).

Empirical assessments, mostly in the form of case studies have investigated the factors driving successful PPPs (Jacobson and Choi, 2008; Trafford and Proctor, 2006; Akintoye et al., 2005, inter alia). In terms of policy outcomes, many studies highlight potential advantages of the PPP model and assess problems encountered with traditional public works projects (Larson, 1995; Glagola and Sheedy, 2002; Chan et al., 2004; Tang et al., 2006). Most of these conclusions stem from the analysis of the incentives generated by each model and not necessarily from an actual comparison of outcomes. In these works, PPPs are understood to induce cross-sector collaboration (Jacobson and Choi, 2008) and risk-sharing (Gaffney et al., 1999), whereas TPCs have restrictive one-size-fits-all bidding processes that are not equally appropriate to each and every project (Tang et al., 2006). Most negative assessments focus on political consequences of PPPs (Flinders, 2005), dilution of political control over policymaking and the generation of low quality jobs (Bovaird, 2004).

Given such a strong expectation of superior PPP performance, the empirical evidence is surprisingly noisy and, at times, contradictory (Hodge and Greve, 2007). The difficulties in determining a counter-factual benchmark against which to judge the performance of PPPs is, perhaps, the greatest impediment to higher-quality evaluations that could yield evidence on the relative performance of PPPs (Hodge and Greve, 2007).

The difficulty lies not in PPPs themselves, but rather, in correctly identifying and appraising the alternative. Studies used to demonstrate the advantages of PPP prior to contracting are frequently legally-mandated and typically fail to adequately detail the cost structure of the "public sector comparator." As detailed by Ball (2011), this problem is common even in countries with significant experience in implementing PPPs, such as Australia and the United Kingdom.

Studies that do compare PPPs with TPC rarely engage in direct comparisons of performance outcomes. For example, the main conclusion in Infrastructure Partnerships Australia's 2007 report 
(IPA, 2007) is that there is greater transparency in PPP projects than in traditional contracting. This conclusion is also shared by the U.K.'s National Audit Office (National Audit Office, 2009). Transparency is of course important, but it is not a comprehensive measure of performance. Similarly, Marin (2009), in his analysis of sanitation projects in the developing world, argues that given the lack of reliable data on the performance of state-provided sanitation services, the impact of PPPs would only be assessed in comparison with pre-PPP outcomes, and not against the concurrent state provision of similar services, as would be desirable. Again, the comparison to pre-PPP outcomes is an interesting second-best scenario, but cannot account for possible changes in the performance of TPC over time.

The World Bank (2014) found that studies focusing on the operational phase of infrastructure projects are even rarer than those assessing the construction phase. Gassner, Popov and Pushak (2009) is an exception that examined the role of private partners in PPPs and other forms of privatizations, including projects related to sanitation and energy services. The study evaluated results in 71 countries and demonstrated that private participation generated efficiency gains such as lower water losses and better management of personnel. In this same vein, recent work by Cabral, Lazzarini and Azevedo (2016) compares the performance of prisons in Brazil that shifted from private to public management for political as opposed to performance reasons. The study finds essentially no change in the quality of service provision after the state took control.

Of the studies examining the construction phase of infrastructure projects, the most notable were conducted by the National Audit Office (2009) in the U.K. and in Australia by Duffield (2008) and Infrastructure Partnerships Australia (2007). These studies include education and health infrastructure projects, among others. The comparison of infrastructure projects across policy areas, however, poses another difficulty. Policy area-specific factors are likely to affect construction costs and time to completion considerably. Because the public entity often adopts the same model for an entire policy area at a given time, a cross-model comparison within a specific policy area is not always feasible. Instead, these studies compare actual costs and completion time to what had been planned, generating a relative measure of predictability across different models.

In the U.K., 31 percent of PPP projects were delayed relative to the original plan, compared to 37 percent of projects in traditional contracting (National Audit Office, 2009). With respect to costs, 35 percent of PPPs and 46 percent of TPC projects went over budget. Even though these results suggest a slight superiority of PPPs, the authors note the limited comparability across the examined projects. In Australia, studies show that over-budget projects are much more common in traditional contracting than in PPPs; delays occurred in about a quarter of the projects under traditional contracting and were all but absent among PPPs (IPA, 2007; Duffield, 2008).

Several countries have been using PPPs to expand infrastructure and access to education. There are education-related PPPs in the U.K., Australia, Canada, Germany, and Holland, among other countries. (LaRocque, 2008). In addition to these, Egypt accepted bids for the construction of more than 300 schools, and there are reports of public-private partnerships for schools in Botswana, as well as universities in the United Arab Emirates (Oyewole, 2009).

The U.K. is, by far, the country with the greatest experience using PPPs in education, with investments of more than $£ 8$ billion (EPEC, 2012). The bulk of these investments comes from the "Building Schools for the Future" (BSF) project. Launched in 2003, BSF is the largest school 
infrastructure project that the U.K. has undertaken in the past fifty years. Its stated objective was to affect 3500 secondary schools (PricewaterhouseCoopers, 2007), though by some estimates the project had reached only 310 schools by 2011 (James, 2011). In that year, the BSF was replaced by a new initiative called "Priority School Building Programme" (PSBP), which featured a more modest goal of building 260 schools during its first stage. Among the changes was the introduction of centralized bidding on projects and the exclusion of "soft services", such as cleaning services, laundry, security, and focusing strictly on services related to building maintenance (Devney, 2015). By 2015, the PSBP had built 16 schools, and 55 others were under construction. In 2015, the government announced a second phase that aimed to build 277 additional schools (Dfe, 2015).

Despite these examples of education-related PPPs, there have been very few evaluations focused on assessing performance. For example, Patrinos, Barrera-Osorio and Guaquetá (2009) argue that the majority of studies examining public-private partnerships in education have prioritized charter schools (in the U.S.) and voucher initiatives (in several other countries). No studies, however, have examined PPPs aimed at constructing and/or operating school infrastructure. Not even in Australia or the United Kingdom (the countries that have implemented the most PPP projects) is there evidence of any rigorous program evaluation (Eggers and Startup, 2006). Studies in Australia have focused on contractual aspects (IPA 2007); studies evaluating U.K. programs have taken a case study approach (Gibbson and Davies, 2008; Nisar, 2007). Among these, Kakabadse, Kakabadse and Summers (2007) is particularly noteworthy. The authors interviewed 27 local school officials in the U.K. and found that 76 percent of respondents evaluated their experience with PPPs as either good or excellent. Although some officials reported a loss of management flexibility, there was a broad consensus that a PPP was the most practical way to take on school building and renovation projects.

In response to the lack of research devoted to the evaluation of PPP experiences around the world, Patrinos, Barrera-Osorio and Guaquetá (2009) recommended and promoted a broader research agenda, calling for studies to examine the performance of PPPs devoted to educational infrastructure. Our paper does exactly this, systematically comparing two groups of schools built at the same time, using two different procurement methods. The projects were implemented in a single large city in the developing world, in which demand for schools vastly outpaces supply.

\section{THE BELO HORIZONTE CONTEXT}

PPPs first came into use in Brazil in 2004, when a new law established two types of infrastructure models: 1) administrative concessions, initiatives wholly funded by the government; and 2) sponsored concessions, projects that are partially or fully funded by user fees (Monteiro, 2015). The academic literature identifies 76 PPP projects in Brazil, most of which were initiated after 2012 by states and municipalities around the country (Pereira, 2015:4). The majority of these were infrastructure projects, such as administrative centers, stadiums, sanitation, street lighting, urban mobility projects, hospitals and prisons. The one-of-a-kind nature of these projects and the fact that they were typically carried out in different jurisdictions, make direct comparisons with the provision through traditional public contracting difficult. Moreover, lack of transparency across many public entities is a further 
impediment to studying these projects. The Belo Horizonte experience with PPPs avoids most of these difficulties.

At the start of his first term as mayor of Belo Horizonte in 2009, Marcio Lacerda declared the expansion of the city's preschools and related infrastructure to be a priority. ${ }^{2}$ Achieving this goal required the construction of a large number of new preschools, formally known as Municipal Youth Education Units (“Unidades Municipais de Educação Infantil”, or Umeis).

At the time, municipalities were legally required to enroll children 6 years of age and older. ${ }^{3}$ Preschool coverage was not uniform nationwide. In Belo Horizonte, coverage stood at $84 \%$ for four and five year olds, and at $28 \%$ for children below three years of age. The movement to expand coverage was already gaining momentum. Soon thereafter, Federal Law 12.796/2013 extended mandatory school coverage nationwide to children aged four and five. In 2014, Brazil's national education plan further established that this expanded coverage target should be met by 2016 . What is more, the new law required coverage to be expanded to 50 percent for children between zero and three years by 2024 .

In 2008, Belo Horizonte had 40 UMEIs. From the start of Lacerda's term through May 2015 (the month this study was initiated), 59 new schools were built (and several other were under construction), expanding coverage to nearly 26,000 children. Over half of the new schools were built through traditional contracting (explained below), but 45 percent of the units were built using a PPP model. In fact, this was the first PPP in Brazil for building and operating education infrastructure. ${ }^{4}$ The initiative was so path-breaking that it was a finalist for the Financial Times "Citi Ingenuity Awards" (Business Wire, 2013), and cited by the Consulting firm KPMG as one of the most innovative infrastructure projects worldwide (KPMG, 2012).

Table 1 provides a year-by-year breakdown by procurement method of Belo Horizonte's UMEI construction effort during Lacerda's two terms in office (2009-2015). Until 2012, only TPC was used. Beginning in 2013, PPP became the prevalent method. The reason for this shift was a realization by government officials that the speed of traditional construction methods was not sufficient as traditional contracting rules impeded progress toward meeting the mayor's announced targets. Moreover, after the passage of the new law in 2013, the commitment to PPPs was strengthened further due to the new nationally mandated targets for coverage.

The Umeis built through traditional contracting were subject to standard rules for public procurement of construction projects in Brazil, a process that can be extremely onerous. The procurement law requires the government to produce studies for each individual project, obtain the permits and licenses, and develop a basic engineering plan or blueprint prior to the construction phase bidding process. In addition, the law stipulates that contracts be short-term, and limited only to the construction of facilities (Gusmão, 2008; Lobato, 2015).

\footnotetext{
${ }^{2}$ Municipalities are governed by elected mayors who serve a 4-year term, and who are allowed to seek immediate reelection once. Marcio Lacerda served two consecutive terms, from 2009 to 2016.

${ }^{3}$ This requirement was laid out by the Brazilian General Education Law (Federal Law number 9.394/96), known as Lei de Diretrizes e Bases da Educação, or simply LDB.

${ }^{4}$ The PPP contract was signed in July 2012.
} 


\begin{tabular}{|c|c|c|c|c|}
\hline & \multicolumn{2}{|c|}{ Umeis Initiated } & \multicolumn{2}{|c|}{ Umeis Delivered } \\
\hline & TPC & PPP & TPC & PPP \\
\hline 2009 & 9 & & 1 & \\
\hline 2010 & 6 & & 5 & \\
\hline 2011 & 2 & & 4 & \\
\hline 2012 & 12 & & 4 & \\
\hline 2013 & 3 & 20 & 6 & 3 \\
\hline 2014 & 1 & 17 & 8 & 17 \\
\hline 2015 & & 7 & 2 & 24 \\
\hline Total & 33 & 44 & 30 & 44 \\
\hline
\end{tabular}

Source: Elaborated by the authors from administrative data.

Due to these requirements, government agencies tend to initially bid out the execution of the blueprint, and then later conduct a second - larger - bidding process for the construction itself. Project efficiency suffers as a result, as the incentives of the contractors hired to generate the blueprint are not aligned with that of the construction firms - or of whomever will operate the asset.

Operation usually falls under the purview of the government agency, which often conducts other bidding processes to outsource some of the maintenance services. In this case, services are contracted separately and principals have an intense work in the coordination of the professionals involved in these non-pedagogical services and in the interaction with different government agencies.

The most deleterious feature of the law, however, is that separate bids must be held for each project. In the case of Belo Horizonte, this meant that the municipality had to conduct a separate bidding process for each and every Umei. This implied the existence of multiple contracts and contractors, many of which were small firms that could not always guarantee service delivery. This resulted in delays, reduced efficiency and dropped contracts.

The administrative burden was, simply put, immense. It limited the government's capacity to build more schools. The government not only lacked construction funds; perhaps more importantly, it also lacked the human resources to plan, conduct the biding and oversee the construction of multiple small projects.

\footnotetext{
${ }^{5}$ The table excludes Umeis that were transferred to the municipality in the period. One TPC Umei delivered in the period was initiated before 2005. The remaining differences between Umeis initiated and those delivered are due to Umeis that were due to be delivered in 2016, after the study was conducted. Our sample is the subset of the units included in this table that were operating for at least six months at the time of the study (i.e. the end of 2015).
} 
For the Umeis built through PPPs, the city resorted to a regime of "administrative concession" in which the private party's revenue is fully provided by government payments. The government provides the basic guidelines for construction, while the contractor is responsible for project engineering, construction and the provision of non-pedagogical services. Government payments were divided into investment compensation and monthly operational costs.

The non-pedagogical post-construction services included in the contract did not include school bus and cafeteria services, but did incorporate building maintenance and conservation, utility connections, supplies, copy services, security, cleaning and laundry services, and intra-unit information-technology (IT) infrastructure (Belo Horizonte, 2015). ${ }^{6}$ In contrast with TPC model, in PPP non-pedagogical services are done by the private partner. In this sense, all the work related to contracting and managing these professionals are concessionary responsibility, freeing principals to pay greater attention to academic concerns.

By transferring risk and project responsibility (including for project management, financing and service provision) to the concessionary, the contract sought to introduce private-sector efficiency in the provision of public services. The contracts also linked operations-related payments to a detailed performance metric, subject to independent third-party auditing.

The private party's obligations in the original 20-year contract included the construction of 30 new Umeis and the rehabilitation of two existing units. ${ }^{7}$ In the PPP, bids were only accepted for the full set of schools (not for individual units) in order to maximize the gains from economies of scale. In 2014, the contract was expanded to include 14 additional Umeis, bringing the total to 44 new units built through the PPP. The contract stipulated that the first seven Umeis should be delivered within 12 months, as these units already had detailed construction projects and construction licenses. There was no delivery schedule for the remaining units, only requiring that all be finished within a 24-month period. ${ }^{8}$ Although there was no detailed engineering project for these units, all Umeis are required to follow a common building template, referred to as Type III, ${ }^{9}$ and to adhere to construction practices and patterns already implemented by the municipality in other schools. This meant that all Umeis should be similar in size and scope, ${ }^{10}$ with a maximum capacity of 440 pupils and a constructed area of 1,115 squared meters divided into two floors and with outdoor facilities. The first should include kitchen, cafeteria, pantry (dry and refrigerated), age-appropriate bathrooms, indoor patio, two classrooms for children one and two years old, a multipurpose room, library, diaper changing room, nursery room (for cribs), activity room, a principal and administrative assistant's offices, and elevator. The second floor included eight classrooms for children three to five years old, a meeting room, and age-appropriate bathrooms. The units were also required to include outdoor infrastructure consisting of a parking lot for faculty and staff, a lawn, vegetable garden, playground, auditorium, patio, trash disposal units and adequate cooking gas storage facilities.

\footnotetext{
${ }^{6}$ The city was still required to provide Internet connectivity to the schools and furnish computer equipment.

${ }^{7}$ The contract also included the construction of five new elementary schools, but these are not part of our analysis.

${ }^{8}$ The 24-month period was calculated following a grace period of 30 days after the signing of the contract.

${ }^{9}$ Type III was used both in units built by PPP and in units built concurrently through traditional contracting. According to the city's technical staff, Type III is quite similar to Type IV, which was also used in other units built through traditional contracting during the same period.

${ }^{10}$ These parameters are specified in the document "Anexo 5 - Especificações de Projetos e de Obras das Unidades de Ensino, p. 2", available as suplemental material to this article.
} 


\section{THE BELO HORIZONTE EXPERIENCE AS A QUASI EXPERIMENT}

The essential assumption of this study is that the Umeis built in Belo Horizonte between 2009 and May 2015 using traditional contracting are, as a group, very similar to the Umeis built using PPP contracting in the same city during the same period. As the Umeis were not randomly assigned to the two procurement methods, this assumption requires some justification.

As a preliminary point, not all of the Umeis delivered in the period under analysis were in fact similar. Umeis differed, for instance, with respect to the type of construction. According to municipal government staff, construction types were usually associated with particular topographic characteristics of the plots that made construction considerably harder (or easier). However, types III and IV - which account for more than half of the Umeis delivered - were completely equivalent and comparable. In fact, these two types were usually merged together in government documentation, as they had identical architectural characteristics that diverged only in terms of finishing and structural materials.

We have therefore restricted our analysis to the 46 Umeis of type III and IV that were in operation for a minimum of six months at the time of data collection. Of these, 27 were built using PPP contracting, and 19 by TPC. Although construction through PPP started later, more than half of the TPC Umeis in our sample were delivered in 2013 and 2014, the same years in which most of the PPP Umeis in the sample were completed.

PPP and TPC Umeis in our sample also share geographic similarities, in terms of where they were built. The criteria for including an Umei in the PPP contract included i) the existence of demand for the school based on socioeconomic indicators; ii) the existence of plots of land that were already owned by the government or that could easily be acquired; and iii) a requirement that the plot not already be in use or already a part of a traditional bidding process.

The first two criteria were common for both PPPs and TPC units. The third requirement was driven by the timing of the decision to shift to PPPs. We argue that it is unrelated to the outcomes that we evaluate, as it should neither affect the time to construction of the specific unit nor the difficulty in operating it.

If the two types of units were built in neighborhoods with different socioeconomic indicators, they might not be directly comparable. The relevance of this potential confounder is more appropriate for the analysis of operation-phase outcomes. For example, if the city had first built units in the poorest neighborhoods and subsequently in better-off areas, one could argue that it would be harder to operate the former than the later. Such differences could also affect construction time, as it is conceivably more challenging to build in poorer districts due to differences in ease of access, security and existing infrastructure.

Fortunately, the available data suggest that this is not the case. The two groups of Umeis are, in fact, well balanced on observable indicators such as the regional social vulnerability Index ("Índice de Vulnerabilidade Social", or IVS). ${ }^{11}$ In addition, both types of contracting methods were used in six of the nine administrative regions, which implies considerable geographic overlap. ${ }^{12}$

\footnotetext{
${ }^{11}$ The IVS is an index that computes an inclusion/exclusion ratio for the population of each region of the city. The index is based on public access to infrastructure, as well as access to cultural, economic, legal and health services (Nahas, 2000; Belo Horizonte, 2000). ${ }^{12}$ TPC units were constructed in Barreiro, Centro-sul, Leste, Noroeste, Norte, Oeste, Pampulha and Venda Nova. PPP units were built in Barreiro, Leste, Nordeste, Norte, Oeste, Pampulha and Venda Nova.
} 
The two groups of Umeis are nearly identical with respect to average socioeconomic characteristics. These characteristics, presumably, could affect the subsequent functioning of each unit, as the difficulty of providing certain services could vary with the socioeconomic characteristics of the region in which each school is located. The average of the two groups are very similar across the available demographics for the regions in which each unit was built, such as the human development index (HDI) and education sub-index (HDI-ED), life expectancy and income (see table 2). We report standardized average differences between the two groups, and p-values of $t$-tests of the differences for each attribute - though it is not clear that this is the most suitable metric for assessing balance (see, for example, Ho et al., 2007). The Hansen-Bowers omnibus test for overall differences on these four socio-demographics yields a statistic of 4.66 , with a corresponding p-value of 0.324 , an indication that we cannot rule out that the two groups are identical (Hansen and Bowers, 2008).

These data support our assertion that we can treat the two groups as if the mode of contracting had been randomly assigned, at least with respect to the post-construction operational outcomes. In fact, as we later demonstrate, the differences in operation outcomes are not particularly sensitive to the inclusion of sociodemographic controls, which would be expected with as-if-random assignment.

\section{TABLE 2 CHARACTERISTICS OF PPP AND TPC UMEI GROUPS}

\begin{tabular}{|c|c|c|c|c|}
\hline & TPC & PPP & St. Mean Diff & $p$-value \\
\hline Administrative Regions & $8 / 9$ & $7 / 9$ & & \\
\hline \multicolumn{5}{|c|}{ Socio-demographics (averages) } \\
\hline HDI & 0.80 & 0.79 & -0.207 & 0.488 \\
\hline HDI-ED & 0.73 & 0.72 & -0.221 & 0.458 \\
\hline Life Expectancy & 78.08 & 77.92 & -0.097 & 0.744 \\
\hline Per Capita Income & 1084.2 & 890.8 & -0.363 & 0.228 \\
\hline \multicolumn{5}{|l|}{ Construction (averages) } \\
\hline Area $\left(m^{2}\right)$ & 1089.2 & 1415.4 & 0.427 & 0.158 \\
\hline Type of Building (Type III) & 0.58 & 1 & 1.298 & $<0.01$ \\
\hline Type of Plot (Sloped) & 0.32 & 0.82 & 1.157 & $<0.01$ \\
\hline
\end{tabular}

Source: Elaborated by the authors.

Table 2 also shows that two groups are not identical with respect to all characteristics that could affect the construction difficulty. First, all PPP Umeis were of Type IV, whereas some TPC Umeis 
were also of Type III. Government functionaries maintain that the differences between these two types are quite minor. In addition, there was a greater prevalence of sloped plots in the PPP units and of flat plots in the TPC units. ${ }^{13}$ If anything, this difference should have made it harder to build the PPP Umeis (indeed, this observation is contrary to the results we find later in the text). Fortunately, building area is essentially identical across both types of contracting, an important variable which could have significant impacts on construction time. Still, given this imbalance between the groups, we control for these characteristics when checking the robustness of our results.

Government officials insisted that the type of contracting was not defined based on plot characteristics, so while we recognize the imbalance with respect to type and plot characteristics, we feel justified in controlling statistically for these differences later in the analysis of time-to-delivery. As we will demonstrate, inclusion of these controls does not affect the results of our analysis.

\section{DATA AND METHODS}

We compare the two groups of UMEIs by examining one outcome from the construction phase, and several outcomes from the operational phase. For all outcomes, we compared the two groups through formal difference of means or difference in proportions tests. Given our assumption of as-if-random selection into either group, this simple comparison is enough to examine whether performance differs across the two contracting models.

For each comparison, we also estimate the difference between the PPP and the TPC groups, controlling for potential confounders. This is particularly important for the construction outcome phase, as we detected some imbalance on plot characteristics and other variables that could affect construction time. While we did not find such an imbalance on variables that could affect operational outcomes, we opted to present results controlling for the Human Development Index (HDI) of the region of each Umei in order to serve as a robustness check for the results. In both cases, the specification with controls also provides an additional check on our research design as a whole, as our "as-if-random" assignment assumption would imply that any results should be stable in the presence of controls.

\subsection{CONSTRUCTION-PHASE OUTCOME}

The construction-phase outcome of interest is construction time, measured as time-to-delivery from the start of construction. Here we focus not only on a comparison of means of the two groups, but also of standard deviations, as the variance of the time-to-completion is a measure of uncertainty and therefore also substantively relevant. We constructed this variable from administrative records obtained from the city's education secretariat ("Secretaria Municipal de Educação", or SME) and from the infrastructure development agency ("Superintendência de Desenvolvimento da Capital", or Sudecap). Sudecap also provided the data on the type of construction.

\footnotetext{
${ }^{13}$ We coded this variable from the individual reports issued on each plot. We coded plots as "flat" when little or no preparation was needed to level the plot. This included situations in which part of the plot was flat enough to build on, even if parts of the plot were sloped.
} 
For the PPP units, time to construction was calculated as the period between the date that the construction permit ("alvará") was issued by the relevant government agency and the date that the "Provisional Term of Acceptance" ("Termo de Recebimento Provisório") was signed by the relevant municipal official. For the TPC Umeis, start of construction is indicated by a service order issued by Sudecap; delivery is marked by a transfer document between Sudecap and the representative of the regional office of the city government. We cannot use the exact same makers of beginning and end of the construction phase because the two types of procurement systems are different. To the best of our knowledge, however, these milestones used here are thoroughly comparable. Moreover, in both cases, the event that marks the start of the construction phase only happens after the plot of land is legally available for development. Any delays in the processing of construction licenses are therefore not included in and do not affect our measure of construction time.

\subsection{OPERATIONAL-PHASE OUTCOMES}

For the operational-phase outcomes, we surveyed the school principals of the Umeis in the sample. The survey was conducted between September $9^{\text {th }}$ and October $2^{\text {nd }}, 2015$, using the electronic platform Qualtrics. The questionnaire was distributed by email to the principals using email addresses provided by the municipal government (and which also approved the study). ${ }^{14}$ After follow-up calls and a considerable amount of effort, we succeeded in obtaining responses from 42 of the 46 units in the sample (91.3 percent), 24 of which were PPPs and 18 of which had been built under traditional contracting.

The survey (reproduced in full in the Supplemental Information materials) yielded data that allow us to investigate differences across both types of contracting models. These differences include the share of time principals devote to pedagogical activities, as well as measures of their satisfaction with services provided by the municipality to TPC Umeis, or by the private party in the case of PPP Umeis. The types of services in the survey were speed and quality of infrastructure maintenance services, cleaning \& laundry services, IT support services and Internet access. ${ }^{15}$ For the PPP Umeis only, we also assessed principals' satisfaction with help-desk and administrative support services. As these services were not available to TPC principals, we cannot compare these outcomes across both contracting types.

\section{RESULTS}

For clarity of presentation, we separate the results into construction-phase and operational-phase outcomes.

\subsection{RESULTS FOR CONSTRUCTION OUTCOMES}

Time-to-delivery was 19.8 months in the TPC group and 10.9 months for the PPP group, meaning that PPP schools were built almost twice as fast as the TPC units. ${ }^{16}$ This difference of 8.9 months was

\footnotetext{
${ }^{14}$ We obtained authorization from the SME on July 9th, 2015.

${ }^{15}$ We also evaluated principals' satisfaction with help-desk and administrative support services. As these services are not offered to the TPC group, we do not report them here, but include the results in the Supplemental Materials.

${ }^{16}$ These results are not driven by outliers; the median time to completion was 19 and 11 months, respectively.
} 
so large that it could preclude a formal statistical test. Still, as expected, this difference is statistically significant in a 2 -sample $t$-test with separate variances ( $\mathrm{p}$-value $<0.001$ ).

We present two additional estimates of this difference using two different specifications (see table 3). In both additional specifications, we estimate the difference between the two groups by OLS regression with robust standard errors, controlling for the two variables in which there was imbalance between the two groups, as discussed earlier. The first includes indicators for region of the city in which each Umei is located and plot characteristics (i.e. whether the site was flat or not). The second specification includes an indicator for construction type (i.e. whether construction type was III or IV).

The most important results are shown in the first rows of the table. Whereas region and plot characteristics have almost no effect on the result, the inclusion of construction type does reduce the effect of PPP, though construction type is not statistically significant. However, even in this last model, the difference attributable to type of contracting is still considerable, with PPP units being built close to 7 months faster than units constructed by TPC. The result for the mode of contracting is statistically significant in all specifications, and the potential confounders are not. The overall conclusion is unambiguous: time-to-delivery was much shorter with PPP than with TPC.

\section{TABLE 3 EFFECTS OF PPP ON TIME-TO-DELIVERY OF UMEIS ${ }^{17}$}

\begin{tabular}{lccc} 
& $\begin{array}{c}\text { Difference in } \\
\text { Means }\end{array}$ & $\begin{array}{c}\text { OLS } \\
\text { (Model 1) }\end{array}$ & $\begin{array}{c}\text { OLS } \\
\text { (Model 2) }\end{array}$ \\
\hline PPP & -8.93 & -8.80 & -6.85 \\
$p$-value & $<0.001$ & $<0.001$ & 0.001 \\
$\begin{array}{l}\text { Plot type } \\
\text { (sloped =1) }\end{array}$ & & \\
$\begin{array}{l}\text { p-value } \\
\text { Construction Type } \\
\text { (type IV=1) } \\
p \text {-value }\end{array}$ & & 1.42 & 1.25 \\
Region Effects & & & 0.340 \\
N & & & 4.654 \\
\end{tabular}

Source: Elaborated by the authors.

The first column reports simple differences in means. OLS denotes regression estimates with clustered standard errors.

\footnotetext{
${ }^{17}$ The outcome variable is time-to-delivery, measured in months. The sample is the same in all specifications.
} 
PPPs dramatically reduced the variability in the time-to-delivery of the units. The standard deviation of the time to completion was 1.3 months in the PPP group and 6.2 months for the TPC group - a difference that is statistically significant using the Brown-Forsythe variant of the Levene test (test statistic $=37.541$, $\mathrm{p}$-value $=<0.001){ }^{18}$

Considering the 13-month contractually-promised time-to-delivery for the TPC method, the difference is stark: 79 percent of units contracted through TPC were delivered late, while all PPP units would have been delivered ahead of schedule.

\subsection{RESULTS FOR OPERATIONAL OUTCOMES}

The first - and perhaps most instructive - operational outcome of interest is whether principals are able to devote more attention and effort to pedagogical (as opposed to administrative) activities. We examined this issue by asking principals what share of their time they devoted to pedagogical activities in the school; we then sought to validate the response by inquiring whether principals thought they devoted too much time to non-pedagogical activities.

Principals in the PPP group reported spending 70 percent of their time on pedagogical activities, compared to 56 percent in the TPC group. As reflected in the first rows of table 4, this difference of 14 percentage points is statistically significant, and remains essentially unchanged if we control for the regional HDI (a difference of 26 points, $\mathrm{p}$-value $=0.027$ ). In this specification (see table 4 , column two), we employed robust standard errors clustered at the level of the region because level of development is only available at the level of region, and not at the level of the unit.

In the validation question, we inquired whether principals agreed with a statement that they spent too much time on administrative tasks. Agreement was expressed on a five-point scale, which, for simplicity, we treated as a continuous variable. Higher values denote more agreement with the statement and are interpreted as a normatively negative outcome. Consistent with the results of the previous question, principals of PPP Umeis expressed less agreement with the statement, indicating a superior outcome of this mode of procurement. The result is again essentially the same with or without the control variable.

In and table 6, we report differences between PPP and TPC Umeis with respect to all other operational outcomes for which we collected data. The eight outcomes are grouped into four categories. In each, we report results for the simple difference in means test (DiM), as well as differences estimated by ordinary least squares with standard errors clustered by region (OLSCLSE), controlling for the HDI. As HDI is only available at the region level, and not at the unit level, we also employed robust standard errors clustered at the level of the region.

In these questions, the outcome variable is always measured on a five-point scale on which low values indicate that the principals were very dissatisfied and upper values indicate higher levels of satisfaction. We treated the scale as a linear variable, but similar results hold with other specifications. As the TPC group is the baseline, positive effects indicate that PPP contracting has better evaluations.

\footnotetext{
${ }^{18}$ This variant of the Levene test is based on the absolute deviations from the median (instead of the mean), and is considered much more robust to deviations from the normality assumption.
} 


\section{TABLE $4 \quad$ DIFFERENCES IN PRINCIPALS' TIME DEVOTED TO PEDAGOGICAL ACTIVITIES ${ }^{19}$}

\begin{tabular}{lcccc} 
& \multicolumn{2}{c}{$\begin{array}{c}\text { Share of Time Spent on } \\
\text { Pedagogical Activities }\end{array}$} & \multicolumn{2}{c}{ Spend Too Much Time on Non-Pedagogical } \\
& DiM & OLS & DiM & Activities \\
\hline PPP & 14 & 13.691 & -0.736 & -0.716 \\
$p$-value & 0.028 & 0.030 & 0.064 & 0.068 \\
HDI & & -71.202 & & 4.622 \\
$p$-value & & 0.201 & & 0.236 \\
$\mathrm{~N}$ & & 42 & & 42 \\
\hline
\end{tabular}

Source: Elaborated by the authors.

DiM denotes estimates computed by simple differences in means. OLS denotes regression estimates with clustered standard errors.

In no case does the inclusion of the control substantially change the result with the simple differences in means test. This is further evidence of the validity of the "as-if-random" assumption for the operational outcomes, on which this paper is based.

\section{TABLE 5 DIFFERENCES IN MAINTENANCE AND OPERATIONAL SUPPLIES AND MATERIALS}

\begin{tabular}{|c|c|c|c|c|c|c|c|c|}
\hline & \multicolumn{4}{|c|}{ Maintenance } & \multicolumn{4}{|c|}{ Operational Supplies and Materials } \\
\hline & \multicolumn{2}{|c|}{ Response Time } & \multicolumn{2}{|c|}{ Quality } & \multicolumn{2}{|c|}{ Availability } & \multicolumn{2}{|c|}{ Quality } \\
\hline & DiM & OLS & DiM & OLS & DiM & OLS & DiM & OLS \\
\hline PPP & 1.133 & 1.133 & 1.093 & 1.088 & 0.292 & 0.293 & 0.808 & 0.800 \\
\hline$p$-value & 0.001 & $<0.001$ & 0.002 & $<0.001$ & 0.086 & 0.056 & 0.014 & 0.001 \\
\hline $\mathrm{HDI}$ & & -0.249 & & -4.899 & & -0.449 & & -1.207 \\
\hline$p$-value & & 0.895 & & 0.131 & & 0.81 & & 0.631 \\
\hline $\mathrm{N}$ & \multicolumn{2}{|c|}{39} & \multicolumn{2}{|c|}{41} & \multicolumn{2}{|c|}{41} & \multicolumn{2}{|c|}{39} \\
\hline
\end{tabular}

Source: Elaborated by the authors.

DiM denotes estimates computed by simple differences in means. OLS denotes regression estimates with clustered standard errors.

\footnotetext{
${ }_{19}$ Table 5 shows results for two dependent variables: share of time spent with pedagogical activities and agreement with the statement that the principal spends too much time engaged in non-pedagogical activities. The first estimate in each case is a simple difference in means (DiM), whereas the second estimate is derived by ordinary least squares with robust standard errors (OLS Cl SE). P-values are shown in italics.
} 
PPPs garnered more satisfaction of principals with respect to both response time and quality of maintenance services. Results for these items are not only highly statistically significant ( $\mathrm{p}$-values $<0.01$ ); they are also substantively large, as they add up to more than one point on the five-point answer scale, which in this case also corresponds to just over one standard deviation of the distribution of answers.

For administrative support services, PPP receives similarly higher scores on the quality of operational supplies and materials (e.g. cleaning supplies, toilet paper, linens, towels, etc.). For material availability, the difference is less pronounced and somewhat noisier than the other items, but still clearly favors PPP.

Interestingly, PPPs performed worse than TPC with respect to IT services quality and response time, though the difference was only statistically significant for the former. Similarly, there was essentially no difference between the groups with respect to availability or speed of Internet services.

\section{TABLE 6 DIFFERENCES IN IT SUPPORT AND INTERNET SERVICES}

\begin{tabular}{|c|c|c|c|c|c|c|c|c|}
\hline & \multicolumn{4}{|c|}{ IT Support } & \multicolumn{4}{|c|}{ Internet } \\
\hline & \multicolumn{2}{|c|}{ Speed } & \multicolumn{2}{|c|}{ Quality } & \multicolumn{2}{|c|}{ Availability } & \multicolumn{2}{|c|}{ Speed } \\
\hline & DiM & OLS & DiM & OLS & DiM & OLS & DiM & OLS \\
\hline PPP & -0.674 & -0.669 & -0.247 & -0.264 & -0.005 & 0.008 & 0.261 & 0.254 \\
\hline$p$-value & 0.007 & 0.011 & 0.416 & 0.181 & 0.987 & 0.983 & 0.466 & 0.374 \\
\hline $\mathrm{HDI}$ & & -2.202 & & -8.303 & & -3.052 & & -3.659 \\
\hline$p$-value & & 0.376 & & 0.011 & & 0.247 & & $<0.001$ \\
\hline $\mathrm{N}$ & & & & & & & & \\
\hline
\end{tabular}

Source: Elaborated by the authors.

DiM denotes estimates computed by simple differences in means. OLS denotes regression estimates with clustered standard errors.

Unlike maintenance and administrative materials, responsibility for IT and Internet services in the PPP model is in fact shared between the private party and the city. The contractor's responsibility was limited to providing the local wired and wireless network infrastructure, providing switches, access points and other required equipment. The municipality's obligation, on the other hand, was responsibility for the external connection of the unit to the Internet, as well as for the provision and maintenance of computers, servers and printers. This helps explain why results for these outcomes depart from the previous ones, and a point to which we return in more detail in the discussion section.

\section{DISCUSSION}

PPP Umeis outperformed the TPC Umeis in the construction phase (time-to-delivery and predictability) and in six of the ten operational outcomes. Three items showed essentially no difference, and the TPC units outperformed PPP units only with regard with the speed of IT support requests. However, we believe this simple tally understates the superiority of the PPPs in the present case. 
First, consider that PPPs yielded a much lower time-to-delivery and much more predictability of delivery. If there had been no other difference between the two methods of procurement, this would likely be enough to justify the PPPs. Although we were not able to examine the costs of either model, ${ }^{20}$ TPC is probably a costlier type of contracting for the city, as schedule overruns are associated with budget overruns. What is more, a two-year delay in the delivery of a unit impacts approximately 880 pupils. In order to compensate for this, the city pays for non-state service providers, further increasing costs. Moreover, the uncertainty with regard to the delivery of the TPC units makes it harder to plan for the hiring and training of faculty and staff, leading either to redundancies or to understaffing, both of which can be further drains on resources.

Time-to-delivery also affects the capacity of the city to expand its network. Even though the need to build units was a priority from the outset of Lacerda's administration, before adopting the PPP model the city was able to open an average of 4.25 Umeis per year. In the four post-PPP years for which we have data, the city opened an average of 14.7 schools by PPP per year despite the fact that it also increased the number of TPC units delivered to 5.7 Umeis per year. That is, PPPs considerably increased the city's capacity to build schools. This result is compatible with the conclusions in Kakabadse, Kakabadse and Summers (2007), to whom public officials confided that PPPs are sometimes the only model to achieve large-scale school construction projects.

PPP units exhibited better performance than TPC units in reducing principals' administrative workload, freeing them to pay greater attention to academic concerns. This is probably the most important consequence of the operational outcomes. Although we do not have any student performance statistics or data from teachers, we believe the principals' time-allocation to be an acceptable proxy for the overall level of care and attention paid to teaching (which should be the primary concern of schools). Our results are in line with those of Patrinos, Barrera-Osorio and Guaquetá (2009) and IFC (2013), who suggest that relieving teaching staff from non-pedagogical work improves the quality of the infrastructure services while improving learning.

The issues in which PPPs did not outperform TPCs are all related to technology. Here, the shared responsibility for these outcomes is the likely explanation. Not only is it probably harder for principals and other stakeholders to determine who is responsible for any given problem, the solution itself may require action on the part of both the contractor and the government. In fact, when our results were presented to the principals, several pointed out that as the government was responsible for most of the IT services, whenever they faced a problem they tended to contact the government and not the contractor. There was a consensus that IT services were simply not that relevant in the present case because of the age range of the children being served. When all is said and done, underperformance in the IT-related services is not likely attributable to the PPP model, and not a central point of concern for the principals.

\footnotetext{
${ }^{20}$ Comparing costs was our first research idea. However, it is impossible to obtain construction costs for specific units built through PPP, because public payments consider construction and operation together. It is also impossible to obtain operational costs for individual units operated by the municipality as many services are pooled across units.
} 


\section{CONCLUSION}

This article presented a direct comparison of public-private partnerships and traditional public contracting for the construction and operation of preschool infrastructure. It analyzed the case of Belo Horizonte, a large Brazilian city, in which similar schools were built during the same period using both contracting models. We argue that this scenario creates a quasi-experiment, and therefore we are able to employ simple statistical analysis in order to examine performance differences across the two groups of schools. We collected data from administrative records on time-to-delivery of the school units and conducted a survey with the principals of both types of schools in order to examine operational outcomes. Umeis contracted by PPP outperformed TPC in most categories.

Three caveats are in order. First, one important limitation of our study is that the PPP model implemented in Belo Horizonte differs from TPC in several aspects beyond construction planning, financing, execution and post-construction equipment operation. Beyond these more "core" aspects of the PPP/TPC distinction, Belo Horizonte also diverged with respect to other characteristics across these two modes of procurement. The rules governing TPC in Brazil induce contracting on a schoolby-school basis, requiring a separate bidding process for each, allowing for relatively small firms to compete and with limited economies of scale. In contrast, the PPP was implemented as a single package, increasing the project size, restricting potential bidders to larger firms and generating economies of scale. As such, in Belo Horizonte the differences in performance can be attributed to the complete bundle of policies represented by the PPP. A corollary of this point is that it is probably possible to improve TPC as practiced in Brazil, by marginally tweaking some of its features.

There are aspects of the Belo Horizonte case that should give analysts and policymakers pause before generalizing the results. The expansion of school infrastructure was a high priority for the administration, and part of a well-communicated long-term project. The city was also able to seek expert advice from the Brazilian Development Bank (BNDES) and the International Finance Corporation (IFC), which helped structure the PPP. Finally, as this was both a flagship program and the first of its kind, all public entities had a particular interest in working with the contractor to make the project succeed, with an aim toward replicating the initiative elsewhere. As such, the Belo Horizonte experience incorporates almost all of the factors that the literature finds important for the success of PPPs, such as specific plan/vision, commitment, willingness to compromise and expert advice (see Jacobson and Choi, 2008; Trafford and Proctor, 2006; Sagalyn, 2007; Zhang, 2005).

Our analysis does not examine costs. As in previous studies, this limitation stems from the inability to account for operational costs in the TPC schools, which are ran and paid by the government. The difficulty arises because some services provided in TPC are part of larger outsourcing contracts (spanning multiple government agencies), while others are provided directly by different government agencies, for which it is difficult to assign a monetary value. We strongly suspect the much longer time-to-delivery in TPC units to be associated with cost overruns and high opportunity costs for the public service. If it were possible to conduct a proper cost-benefit analysis, we suspect that it would therefore also be favorable to the PPPs. However, such claims remain largely speculative at this point. With these caveats in mind, our direct comparison of the two modes of contracting is amply superior to the PPP, and particularly in contexts of limited state capacity to oversee a rapid expansion of services for which demand is high. 


\section{REFERENCES}

AKINTOYE, Akintola; CHINYIO, Ezekiel. Private Finance Initiative in the healthcare sector: trends and risk assessment. Engineering, Construction and Architectural Management, v. 12, n. 6, p. 601-616, 2005.

BALL, Robert. Provision of public service infrastructure - the use of PPPs in the UK and Australia. International Journal of Public Sector Management, v. 24, n. 1, p. 5-22, 2011.

BELO HORIZONTE. $B$ H metas e resultados: expansão da educação infantil. 2015. Available at: <http:// bhmetaseresultados.pbh.gov.br/content/expansaoda-educacao-infantil > . Accessed on: 27 June 2015.

BELO HORIZONTE. Edital e Contrato da Parceria Público-Privada das Umeis. 2015. Available at: $<$ http://portalpbh.pbh.gov.br/pbh/ecp/comunidade. do? evento $=$ portlet $\&$ pIdPlc $=$ ecp Taxonomia MenuPortal \& ap p = p p peducacao \&tax $=24123 \&$ lang $=$ pt_BR\&pg $=9061 \& \operatorname{taxp}=0 \&>$. Accessed on: 27 June 2015.

BELO HORIZONTE. Expansão da Rede Municipal de Atendimento à Educação Infantil e ao Ensino Fundamental. In: CONGRESSO NACIONAL DE GESTÃO PÚBLICA, 5., 2015, Brasília. Anais... Brasília: Conagesp, 2015. p. 1-19.

BELO HORIZONTE. Plano estratégico de Belo Horizonte 2030: BH no rumo certo. 2. versão. Belo Horizonte: Prefeitura de Belo Horizonte, 2011.

BENNETT, John; IOSSA, Elisabetta. Delegation of contracting in the private provision of public services. Review of Industrial Organization, v. 29, n. 1, p. 75-92, 2006.

BOVAIRD, Tony. Public-private partnerships: from contested concepts to prevalent practice. International Review of Administrative Sciences, v. 70, n. 2, p. 199-215, 2004.

BOWERS, Jake; FREDRICKSON, Mark; HANSEN, Ben. RItools: randomization inference tools. R package version 0.1-13. Viena: The R Foundation, 2016.

BRAZIL. Lei $n^{\circ}$ 8.987, de 13 de fevereiro de 1995. Dispõe sobre o regime de concessão e permissão da prestação de serviços públicos previsto no art. 175 da Constituição Federal, e dá outras providências. Brasília, DF: Casa Civil, Feb. 1995.
BRAZIL. Lei no 11.079, de 30 de dezembro de 2004. Institui normas gerais para licitação e contratação de parceria público-privada no âmbito da administração pública. Brasília, DF: Casa Civil, Dec. 2004.

BRAZIL. Lei $n^{\circ} 12.796$, de 4 de abril de 2013. Altera a Lei $\mathrm{n}^{\circ}$ 9.394, de 20 de dezembro de 1996, que estabelece as diretrizes e bases da educação nacional, para dispor sobre a formação dos profissionais da educação e dar outras providências. Brasília, DF: Casa Civil, abr. 2013. Available at: <www.planalto. gov.br/ccivil_03/_ato2011-2014/2013/lei/112796. htm>. Accessed on: 27 June 2015.

BRAZIL. Ministério da Administração Federal e Reforma do Estado. Plano diretor da reforma do aparelho do Estado. Brasília: Imprensa Nacional, 1995.

BUSINESS WIRE. Financial Times e Citi indicam finalistas para 2013 FT/Citi Ingenuity Awards. 2013. Available at: <www.businesswire.com/news/ home/20131002006555/pt/>. Accessed on: 30 June 2015.

CABRAL, Sandro; LAZZARINI, Sergio G.; AZEVEDO, Paulo F. Private entrepreneurs in public services: a longitudinal study of outsourcing and statization in prisons. Strategic Entrepreneurship Journal, v. 7, n. 1, p. 6-25, 2013.

CHAN, Albert P. C. et al. Exploring critical success factors for partnering in construction projects. Journal of Construction Engineering and Management, v. 30, n. 2, p. 188-198, 2004.

DFE. Department for Education. 6 billion investment to rebuild and improve schools across England. 2015. Available at: <www.gov.uk/government/news/6billion-investment-to-rebuild-and-improveschools-across-england $>$. Accessed on: 30 June 2015.

DEVNEY, Simon. UK government approach to schools private finance. UK Funding Education Agency, 2015. Available at: <www.fespsp.org.br/ reinounido2015/workshop/UK\%20Govt.pdf $>$. Accessed on: 23 Sept. 2015.

DUFFIELD, Colin F. Report on the performance of PPP projects in Australia when compared with a representative sample of traditionally procured infrastructure projects. Parkville: The University of Melbourne, 2008. 
EGGERS, William D.; STARTUP, Tom. Closing the infrastructure gap: the role of public-private partnerships. New York: Deloitte, 2006.

EPEC. European PPP Expertise Centre. United Kingdom - England: PPP units and related institutional framework. 2012. Available at: <www.eib.org/mwg-internal/de5fs23hu73ds/ progress?id=0Ij7JnLLZPJmehl-GbelwQqyY-QGG74U1_0QJZR4v4>. Accessed on: 23 Sept. 2015

FLINDERS, Matthew. The politics of publicprivate partnerships. British Journal of Politics and International Relations, v. 7, n. 2, p. 215-239, 2005.

GAFFNEY, Declan et al. PFI in the NHS: is there an economic case? British Medical Journal, v. 319, n. 7202, p. 116-119, 1999.

GASSNER, Katharina; POPOV, Alexander; PUSHAK, Nataliya. Does private sector participation improve performance in electricity and water distribution? Washington, DC: World Bank, 2009.

GIBBSON, Helen; DAVIES, Brent. The impact of public private partnerships on education: a case study of Sewell Group Plc and Victoria Dock Primary School. International Journal of Educational Management, v. 22, n. 1, p. 74-89, 2008.

GLAGOLA, Charles R.; SHEEDY, William M. Partnering on defense contracts. Journal of Construction Engineering and Management, v. 128, n. 2, p. 127-138, 2002.

GUSMÃO, José Reinaldo Luna. Planejamento na contratação de obras públicas: estudo das disposições legais sobre projeto básico, licenciamento ambiental, definição dos custos e fonte dos recursos no processo de contratação de empreendimentos públicos. 67 f. 2008. Monograph (MBA in Construction Management) - Escola Politécnica, Universidade Federal da Bahia, Salvador, 2008.

HANSEN, Ben B.; BOWERS, Jake. Covariate balance in simple, stratified and clustered comparative studies. Statistical Science, v. 23, n. 2, p. 219-236, 2008.

HART, Oliver; SHLEIFER, Andrei; VISHNY, Robert $\mathrm{W}$. The proper scope of government: Theory and an application to prisons. Quarterly Journal of Economics, v. 112, n. 4, p. 1127-1161, 1997.

HO, Daniel E. et al. Matching as nonparametric preprocessing for reducing model dependence in parametric causal inference. Political Analysis, v. 15, n. 3, p. 199-236, 2007.

HODGE, Graeme; GREVE, Carsten. Public-private partnerships: an international performance review. Public Administration Review, v. 7, n. 3, p. 545-558, 2007.

IFC. International Finance Corporation. Learning PPPs. Washington, DC: Handshake, 2013. Available at: <https://pppknowledgelab.org/handshake>. Accessed on: 23 Sept. 2015.

IPA. Infrastructure Partnerships Australia. Performance of PPPs and traditional procurement in Australia. Sidney: The Allen Consulting Group, 2007. Available at: <www.irfnet.ch/filesupload/knowledges/IPA_Performance\%20of\%20 PPPs_2007.pdf>. Accessed on: 23 Sept. 2015.

JACOBSON, Carol; CHOI, Sang Ok. Success factors: public works and public-private partnerships. International Journal of Public Sector Management, v. 21, n. 6, p. 637-657, 2008.

JAMES, Sebastian. Review of education capital. London: Crown, 2011.

KAKABADSE, Nada K.; KAKABADSE, Andrew P.; SUMMERS, Nick. Effectiveness of private finance initiatives (PFI): study of private financing for the provision of capital assets for schools. Public Administration and Development, v. 27, n. 49-61, 2007.

KPMG INTERNATIONAL. Infrastructure 100: world cities edition. Amstelveen: KPMG, 2012.

LAROCQUE, Norman. Public-private partnerships in basic education: an international review. Reading: CfBT Education Trust, 2008.

LARSON, Erik. Project partnering: results of study of 280 construction projects. Journal of Management in Engineering, v. 11, n. 2, p. 30-35, 1995.

LEIRINGER, Roine. Technological innovation in PPPs: incentives, opportunities and actions. Construction Management and Economics, v. 24, n. 3, p. 301-308, 2006.

LI, Bing et al. Critical success factors for PPP/ PFI projects in the UK construction industry. Construction Management and Economics, v. 23, n. 5, p. 459-471, 2005. 
LOBATO, Marcelo C. E S. Licitações de obras públicas pela Lei $n^{\circ} 8.666 / 93$. Brasília: Advocacia Geral da União, 2015. Available at: <www.agu.gov. br/page/download/index/id/16859616>. Accessed on: 10 Oct. 2015.

MARIN, Philippe. Public-privatepartnerships for urban water utilities: a review of experience in developing countries. Washington, DC: World Bank, 2009.

MONTEIRO, Vera. Aspectos legais da experiência brasileira na modelagem de concessão e propostas para melhorar as normas vigentes. In: PINHEIRO, Armando Castelar et al. (Org.). Estruturação de projetos de PPP e concessão no Brasil: diagnósticos do modelo brasileiro e propostas de aperfeiçoamento. São Paulo: International Finance Corporation, 2015.

NAHAS, Maria Inês Pedrosa. Metodologia de construção de índices e indicadores sociais, como instrumentos balizadores da gestão municipal da qualidade de vida urbana: uma síntese da experiência de Belo Horizonte. In: HOGAN, Daniel (Org.). Migração e ambiente nas aglomerações urbanas. Campinas: Unicamp, 2001. p. 465-487.

NAO. National Audit Office. PFI: construction performance. London: NAO, 2003.

NAO. National Audit Office. Performance of PFI construction. London: NAO, 2009.

NISAR, Tahir M. Value for money drivers in public private partnership schemes. The International Journal of Public Sector Management, v. 20, n. 2, p. 147-156, 2007.

OYEWOLE, Bayo. Public-private partnerships in education. In: PPPs FOR SOCIAL SERVICES AND INFRASTRUCTURE SEMINAR, Accra, 2009. Proceedings... Washington, DC: International Finance Corporation, 2009. p. 1-22.

PATRINOS, Harry A.; BARRERA-OSORIO, Felipe; GUAQUETÁ, Juliana. The role and impact of public- private partnerships in education. Washington, DC: The World Bank, 2009.

PEREIRA, Bruno. Panorama das PPPs no Brasil. In: INTERNATIONAL MEETING INFRASTRUCTURE AND PPP'S, 2015, Brasília. Anais... Brasília: CBIC, 2015. p. 1-13.

PRICEWATERHOUSERCOOPERS. Delivering the PPP promise: a review of PPP issues and activity. Londres: PricewaterhouseCooper, 2005.

PRICEWATERHOUSECOOPERS. Evaluation of building schools for the future. London: Department for Children Schools and Families, 2007.

REVISTA Planejar BH, Belo Horizonte, ano 2, n. 8, 2000 .

SAGALYN, Lyanne B. Public/private development: lessons from history, research, and practice. Journal of the American Planning Association, v. 73, n. 1, p. 7-22, 2007.

TANG, Wenzhe; DUFFIELD, Colin F.; YOUNG, David M. Partnering mechanism in construction: an empirical study on the Chinese construction industry. Journal of Construction Engineering and Management, v. 132, n. 3, p. 217-229, 2006.

TRAFFORD, Sue; PROCTOR, Tony. Successful joint venture partnerships: public-private partnerships. International Journal of Public Sector Management, v. 19, n. 2, p. 117-129, 2006.

WORLDBANK. Public-private partnerships: reference guide version 2.0. Washington, DC: World Bank, 2014. Available at: <www.initiative-pppafrique.org/content/download/990/7987/version/2/ file/PPPreferenceguide2.0_PPIAF.pdf $>$. Accessed on: 23 Sept. 2015.

ZHANG, Xueqing. Critical success factors for public-private partnerships in infrastructure development. Journal of Construction Engineering and Management, v. 131, n. 1, p. 3-14, 2005.

\section{Bruno Rodrigues}

Master of Public Administration, Financial Analyst at Brazilian Development Bank (BNDES).

E-mail: brunor270@gmail.com.

\section{Cesar Zucco}

Ph.D. in Political Science and Associate Professor at Brazilian School of Public and Business Administration / Getulio Vargas Foundation (FGV EBAPE). E-mail: cesar.zucco@fgv.br. 